\title{
Ordovician seawater composition: evidence from fluid inclusions in halite
}

\author{
Fanwei MENG ${ }^{1}$, Yongsheng ZHANG ${ }^{2}$, Anatoliy R. GALAMAY ${ }^{3}, \mathrm{Krzysztof} \mathrm{BUKOWSKI}^{4, *}$, \\ Pei NI ${ }^{5}$, Enyuan XING ${ }^{2}$ and Limin $\mathrm{JI}^{6}$ \\ 1 Chinese Academy of Sciences, State Key Laboratory of Paleobiology and Stratigraphy, Nanjing Institute of Geology and \\ Palaeontology, Nanjing 210008, China \\ 2 Chinese Academy of Geological Sciences, Institute of Mineral Resources, Beijing 100037, China \\ 3 National Academy of Sciences of Ukraine, Institute of Geology and Geochemistry of Combustible Minerals, Naukowa 3A, \\ 79060 Lviv, Ukraine \\ 4 Faculty of Geology, Geophysics and Environmental Protection, AGH University of Science and Technology, \\ Al. A. Mickiewicza 30, 30-059 Kraków, Poland \\ 5 School of Earth Sciences and Engineering, Nanjing University, State Key Laboratory for Mineral Deposits Research, \\ Institute of Geo-Fluid Research, Nanjing, 210093, China \\ 6 Chinese Academy of Sciences, Lanzhou Center for Oil and Gas Resources, Institute of Geology and Geophysics, \\ Lanzhou 730000, China
}

Meng, F., Zhang, Y., Galamay, A.R., Bukowski, K., Ni, P., Xing, E., Ji, L., 2018. Ordovician seawater composition: evidence from fluid inclusions in halite. Geological Quarterly, 62 (2): 344-352, doi: 10.7306/gq.1409

Fluid inclusions in halite can directly record the major composition of evaporated seawater; however, Ordovician halite is very rare. The Ordovician is a key time during the evolution history because profound changes occurred in the planet's ecosystems. Marine life was characterized by a major diversification, the Great Ordovician Biodiversification Event and the Late Ordovician Mass Extinction, the first of the "big five" mass extinctions. However, so far there is no data on the Ordovician seawater. Data from the Ordovician-Silurian boundary were available only. In this study, we report the major compositions from Middle Ordovician halite in China to give the exact composition of Ordovician seawater. The basic ion composition $\left(\mathrm{K}^{+}\right.$, $\mathrm{Mg}^{2+}, \mathrm{Ca}^{2+}$, and $\mathrm{SO}_{4}^{2-}$ ) of inclusion brines was established with the use of ultramicrochemical analysis. The data on the chemical composition of the brines in the primary inclusions indicated that the brines were of $\mathrm{Na}-\mathrm{K}-\mathrm{Mg}-\mathrm{Ca}-\mathrm{Cl}(\mathrm{Ca}-\mathrm{rich})$ type, and cover a huge gap in the evolution of seawater chemistry. The chemical composition of the primary inclusion brine in halite confirmed the earlier results for the Cambrian and Silurian halite originating from other salt basins and the previous speculation of "calcite sea" during the Ordovician, indicating a higher potassium content in the Lower Paleozoic seawater than in the seawater of other periods of the Phanerozoic.

Key words: Ordovician, fluid inclusions, halite, seawater composition, calcite sea.

\section{INTRODUCTION}

The influence of continental, meteoritic waters and groundwaters, as well as other processes, on the change in the composition of marine brines in ancient salt basins is currently discussed (e.g., Klein-BenDavid et al., 2004; Cendón et al., 2008; Garcia-Veigas et al., 2013). There are a number of marine basins, in which the influence of continental factors had a significant impact on the change in the chemical composition of brines (Garcia-Veigas et al., 1995; Ayora et al., 2001; Cendón et al., 2003, 2008). Therefore, the data on the chemical composition of brines of primary inclusions in halite are suitable for the reconstruction of the chemical composition of the Phanerozoic ocean

* Corresponding author, e-mail: buk@agh.edu.pl

Received: Received: September 19, 2017; accepted: January 26, 2018; first published online: May 8, 2018 only when the marine origin of the studied evaporite formations is confirmed by the independent results of palaeogeographic, mineralogical-petrographic and geochemical studies.

To date, models of the chemical composition of the Phanerozoic ocean have been developed based on the chemical composition of the brines of primary inclusions in halite (Kovalevich, 1990; Kovalevich et al., 1998; Lowenstein et al., 2001; Brennan and Lowenstein, 2002; Horita et al., 2002; Kovalevych et al., 2002). These models recognized seawater chemistry variations changing between the $\mathrm{Na}-\mathrm{K}-\mathrm{Mg}-\mathrm{Ca}-\mathrm{Cl}$ (Ca-rich) type and the $\mathrm{Na}-\mathrm{K}-\mathrm{Mg}-\mathrm{Cl}-\mathrm{SO}_{4}\left(\mathrm{SO}_{4}\right.$-rich) type over geologic time. The variations of seawater chemistry in time were correlated with other geological processes on Earth (e.g., changes in seafloor spreading rates, the intensity of magmatic processes, global sea level changes; Horita et al., 2002).

Phanerozoic seawater chemistry oscillated between "calcite sea" (Ca-rich and low-SO ${ }_{4}$ ) type and "aragonite seas" $\left(\mathrm{SO}_{4}\right.$-rich and low-Ca) type with the change of primary mineralogy of non-skeletal limestone (Sandberg, 1983). This is confirmed directly by fluid inclusions contained in marine halite (Kovalevich 
et al., 1998; Lowenstein et al., 2001; Horita et al., 2002; Kovalevych and Vovnyuk, 2010; Brennan et al., 2013), while late-stage potash salts in marine evaporites fluctuated between the $\mathrm{KCl}$ and $\mathrm{MgSO}_{4}$ types with the calcite-aragonite oscillations (Hardie, 1996). During "calcite seas" times (Ca-rich), evaporation and precipitation of $\mathrm{CaSO}_{4}$ completely took all $\mathrm{SO}_{4}^{2-}$ away from the brines during halite formation, leaving $\mathrm{Ca}^{2+}$ in excess in brine. Thus, the remnant brines in fluid inclusions of halite are of $\mathrm{Na}-\mathrm{K}-\mathrm{Mg}-\mathrm{Ca}-\mathrm{Cl}$ (Ca-rich) type, without detectable $\mathrm{SO}_{4}^{2-}$ (Kovalevich et al., 1998; Khmelevska et al., 2000; Petrychenko et al., 2005). The whole time, "aragonite seas" ( $\mathrm{SO}_{4}$-rich and low-Ca), evaporation and precipitation of $\mathrm{CaCO}_{3}$ and $\mathrm{CaSO}_{4}$ took all $\mathrm{Ca}^{2+}$ away from the brines, leaving $\mathrm{SO}_{4}^{2-}$ in excess during the later brine evolution. As a result, the remnant brines in fluid inclusions of halite are of $\mathrm{Na}-\mathrm{K}-\mathrm{Mg}-\mathrm{Cl}-\mathrm{SO}_{4}\left(\mathrm{SO}_{4}\right.$-rich) type without $\mathrm{Ca}^{2+}$ (Khmelevska et al., 2000; Lowenstein et al., 2001; Kovalevych et al., 2009).

Alternatively to these models, the change in the $\mathrm{Ca} / \mathrm{SO}_{4}$ ratio was explained as local environmental changes. Thus, several mechanisms have been proposed to explain the removal of sulphate in evaporite basins: bacterial sulphate reduction of dissolved sulphate, sulphate consumption by calcium-rich inflows related to dolomitization of basement carbonates, and input of calcium-rich hydrothermal infows (Ayora et al., 2001; Cendón et al., 2008; García-Veigas et al., 2011).

Ordovician halite is very rare (Valyashko, 1962; Ronov et al., 1980; Kovalevych et al., 2006b; Fig. 1). Previous data on the Ordovician seawater chemistry come only from the uppermost Ordovician or Upper Ordovician-Lower Silurian deposits of Mallowa Salt in the Canning Basin, Australia (Brennan and Lowenstein, 2002; Horita et al., 2002; Kovalevych et al., 2006b). Their average composition of brines was quite close to the composition of brines of the Early Cambrian and Late Silurian basins, but a signifcant difference is lower potassium content of fluid inclusions from Mallowa Salt (Kovalevych et al., 2006 b). In this paper, we provide data on the seawater chemistry based on a study of fluid inclusions from Middle Ordovician halite of the Ordos Basin in China, thereby covering the gap in the picture of the seawater chemistry evolution (Kovalevich et al., 1998; Lowenstein et al., 2001; Horita et al., 2002).

\section{GEOLOGICAL SETTING}

There are several Ordovician evaporite basins in the North China Platform. One of them is the Ordos Basin - the second largest sedimentary basin in China with an area of $\sim 250,000 \mathrm{~km}^{2}$ (Fig. 2). During the Ordovician, the Ordos Basin

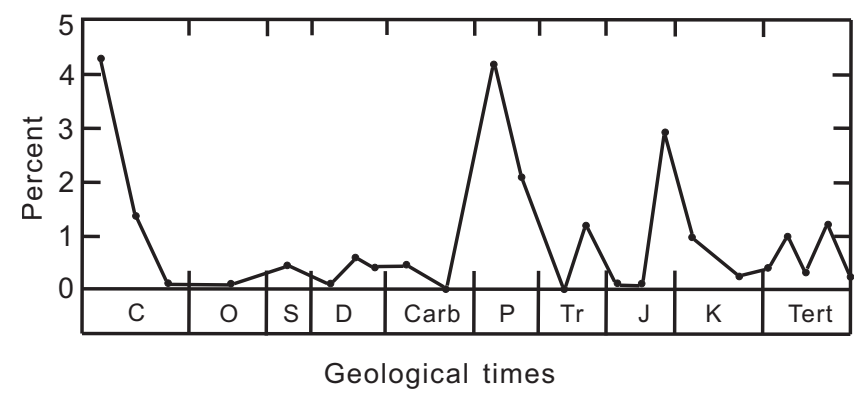

Fig. 1. Variation in abundance of evaporite rocks through Phanerozoic time (after Ronov et al., 1980)

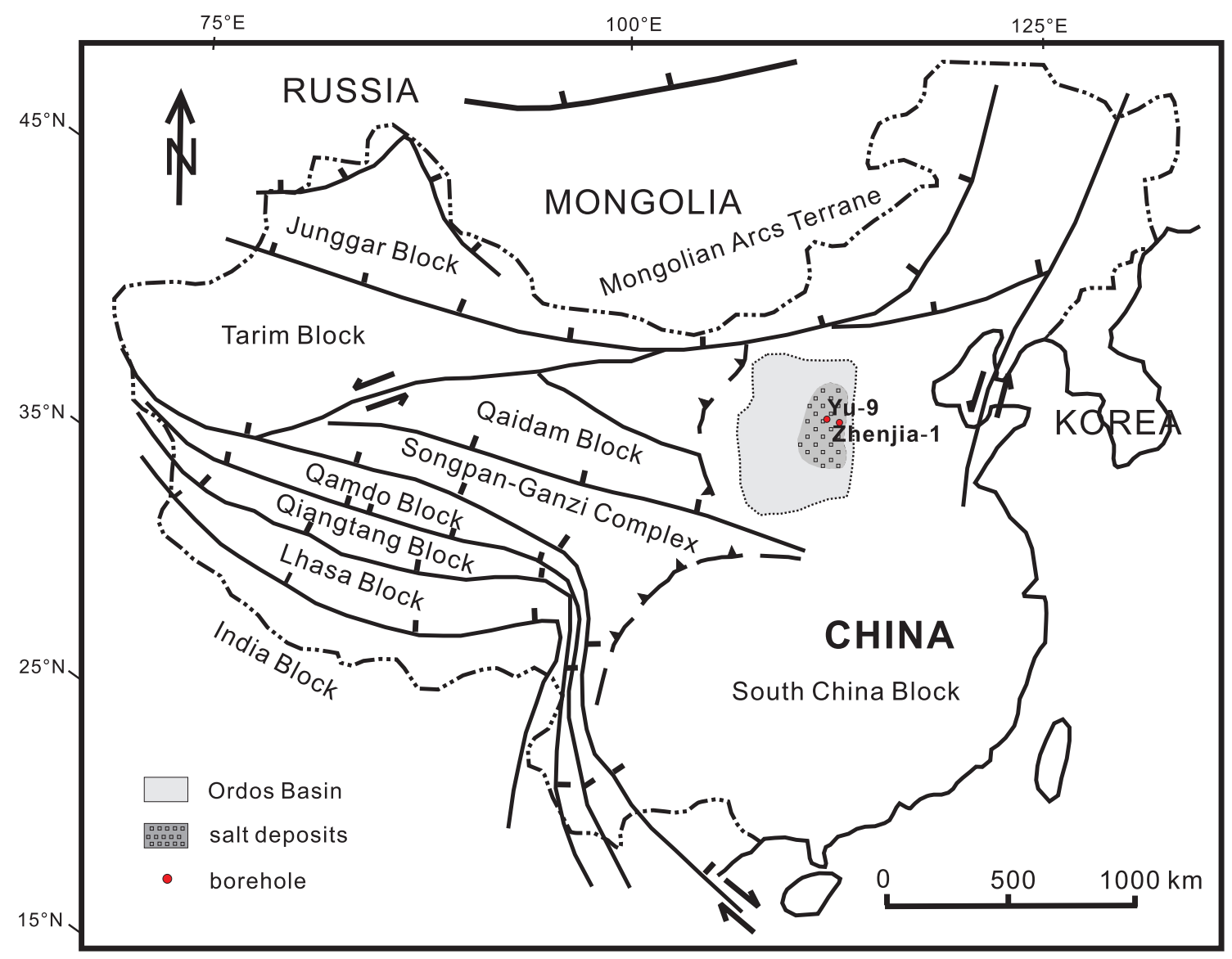

Fig. 2. Location map of the Ordos Basin 
developed a gently inclined carbonate platform in a very shallow epicontinental sea, consisting of carbonates and evaporites. The Middle Ordovician evaporites of the Majiagou Formation developed in a restricted, shallow, and hypersaline environment within the Mizhi Depression (Feng et al., 1998; Wang and Al-Aasm, 2002; Yang et al., 2005; Li et al., 2011). The Majiagou Formation contains carbonates and evaporites and can be divided into six members, from Majiagou Member 1 to Majiagou Member 6 (Table 1; Bao et al., 2004). Majiagou 1, 3, 5 members are mainly evaporites, and Majiagou 2, 4, 6 members are mainly carbonates (Table 1).

The $\delta^{34} S$ values of anhydrite from Ma-5 Member range from +27.1 to $+28.0 \%$ o $(n=5)$ (Yao et al., 2010), and coincide with sulphur isotope of marine Late Ordovician evaporites (mean value +25.5\%) (Fox and Videtich, 1997). These evaporites show a "bull's eye pattern" of facies as not "tear-drop pattern", so the basin was separated from the outer ocean, within which a limited water exchange existed, not strongly affected by inflow of riverine water (Bao et al., 2004). Our Ordovician halite samples come from the Majiagou Member 5 of the Majiagou Formation from the Yu-9 and Zhenjia-1 boreholes, located in the centre of the basin (Fig. 3)

\section{SAMPLES AND FLUID INCLUSIONS}

We have analysed 14 halite samples from two boreholes: Yu-9 $(n=2)$ and Zhenjia-1 $(n=12)$. Of two samples from the Yu-9 borehole - 33[34/61] and 14[2/57] - the latter is nearly devoid of fluid inclusions. Primary and secondary inclusions were revealed in Yu-33 [34/61] (Ma-5 Member, Yu-9 borehole), Zjy-47-21 (Ma-1 Member), and Zjy-24-27 (Ma-6 Member) samples (Zhenjia-1 borehole; Fig. 4).

\section{METHODS}

The analysis of individual brine inclusions was carried out by the ultramicrochemical (UMCA) method (or the method of glass capillaries) of Petrichenko (1973). The method can determine the content of major ions $\left(\mathrm{K}, \mathrm{Mg}, \mathrm{Ca}\right.$ and $\left.\mathrm{SO}_{4}\right)$ in brine inclusions (except for $\mathrm{Na}$ and $\mathrm{Cl}$ ) with an error of $\sim 20 \%$. The method has been used to analyse the ancient seawater chemistry from fluid inclusions of halite (e.g., Kovalevich et al., 1998; Kovalevich et al., 2002; Galamay et al., 2003; Kovalevych et al., 2005, 2006a, b, 2009; Meng et al., 2014).

Chemical composition of inclusion brine was studied in primary fluid inclusions of Zjy-47-21 sample only (Table 2) because the rest of inclusions were too small for UMCA analysis; only 50-100 mm inclusions were used for analyses.

The following methodology was applied for establishing $\mathrm{Br}^{-}$ and $\mathrm{Cl}^{-}$concentrations: firstly, the pure halite samples were dissolved in pure distilled water, followed by oxidation by chloramines $\mathrm{T}$ and chromogenesis achieved using fluorescein. In weak acid solutions, a chemical reaction between $\mathrm{Br}^{-}$and fluorescein produces a strong absorption peak at $510 \mathrm{~nm}$ wavelength, which was measured using a VIS7200 spectrophotometer (Tan et al., 2006).

For chlorine isotopic analysis, we carefully selected pure fragments of halite crystals (with $\mathrm{Cl}^{-}$content $\sim 10 \mathrm{mg} / \mathrm{mL}$ ) under a stereoscopic microscope. These were dissolved in high-purity water produced by sub-boiling distillation. Secondly, we passed the sample solution through a Ba-resin column to remove inter-

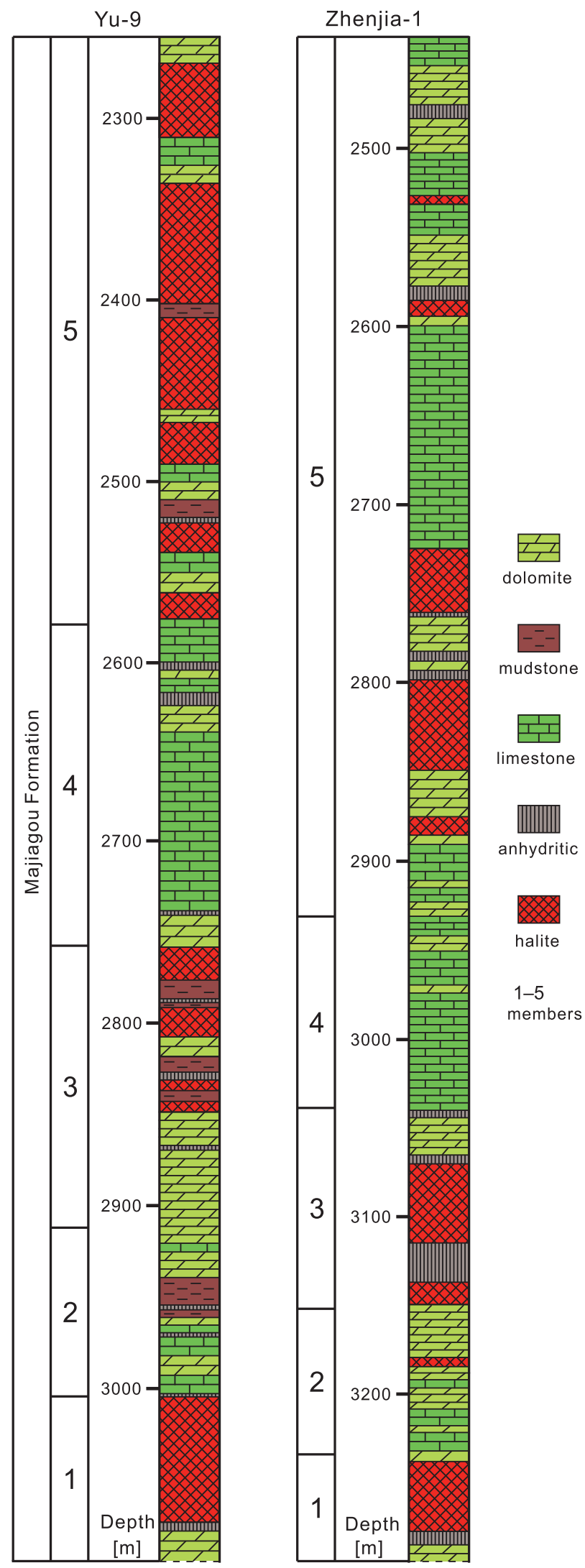

Fig. 3. The lithostratigraphy of drill cores from the Yu-9 and Zhenjia-1 boreholes 
The stratigraphy of Ordovician carbonate and evaporitic rocks of the eastern Ordos Basin (after Bao et al., 2004)

\begin{tabular}{|c|c|c|c|c|}
\hline \multicolumn{3}{|c|}{ Stratigraphy } & \multirow{3}{*}{$\begin{array}{l}\text { Thickness } \\
\text { [m] }\end{array}$} & \multirow{2}{*}{ Lithology } \\
\hline Geological ages & Formation & Member & & \\
\hline Carboniferous & Benxi & & & $\begin{array}{c}\text { upper part is dark grey mudstone interbedded with } \\
\text { coarse-grained lithic quartzose sandstone; basal part } \\
\text { is greyish bauxitic mudstone }\end{array}$ \\
\hline \multirow{7}{*}{ Ordovician } & \multirow{6}{*}{ Majiagou } & Ma 6 & $0-10$ & micrite, absent in most area of the eastern Ordos Basin \\
\hline & & Ma 5 & $220-350$ & $\begin{array}{c}\text { upper part is silty dolomite* and micrite, and lower part is halite, } \\
\text { anhydrite interbedded with silty dolomite }\end{array}$ \\
\hline & & Ma 4 & $120-180$ & mostly micrite with dolomite \\
\hline & & Ma 3 & $80-150$ & silty dolomite, halite and anhydrite \\
\hline & & Ma 2 & $50-110$ & $\begin{array}{l}\text { silty dolomite, argillaceous dolomite and dolomite containing } \\
\text { anhydrite }\end{array}$ \\
\hline & & Ma 1 & $20-80$ & silty dolomite, halite and anhydrite \\
\hline & Liangjiashan-Yeli & & $0-150$ & silty dolomite containing chert beds or nodules \\
\hline Cambrian & Fengshan & & & silty dolomite and spatulate ${ }^{* *}$ dolostone \\
\hline
\end{tabular}

*following Ren et al. (2017: fig. 2f)

**in Chinese literature on the Ordos Basin, "spatulate" is used for a characteristic texture (see Lu et al., 2017: fig. 4)

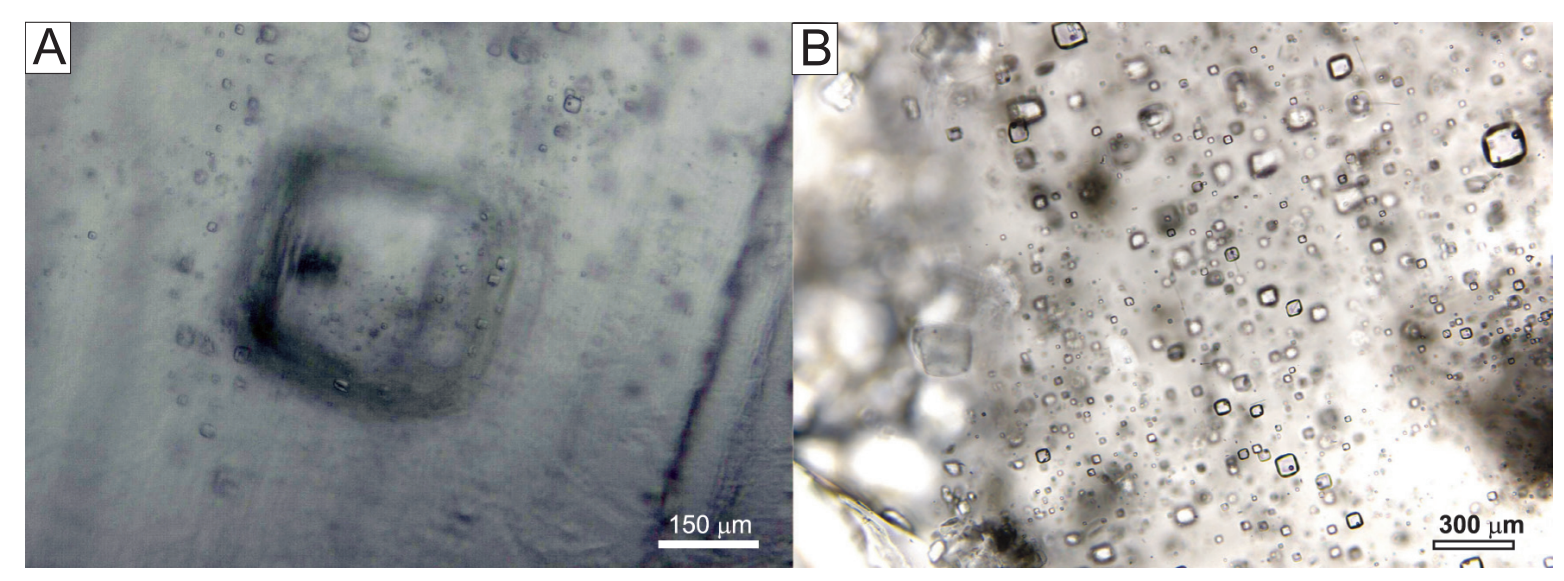

Fig. 4. The remnant primary fluid inclusions in Ordovician halite from the Majiagou Formation of North China

A - halite from the Yu-9 borehole; B - halite from the Zhenjia-1 borehole

Concentrations of major components in primary fluid inclusions of Ordovician halite

\begin{tabular}{|l|c|c|c|c|}
\hline \multirow{2}{*}{ Sample } & \multicolumn{4}{|c|}{ Concentration, g/l (mean value in the parentheses) } \\
\cline { 2 - 5 } & $\mathrm{K}^{+}$ & $\mathrm{Mg}^{2+}$ & \multicolumn{3}{c|}{$\mathrm{Ca}^{2+}$} \\
\hline Zjy-47-21 & $21.4 ; 23.1 ; 21.6 ; 17.3(20.9)$ & $35.9 ; 39.2 ; 48.6 ; 41.5(41.3)$ & $49.8 ; 76.0 ; 55.4 ; 74.6 ; 69.1 ; 71.6(66.1)$ & $<0.5$ \\
\hline \multicolumn{5}{|c|}{ Modern seawater saturated with respect to: } \\
\hline Halite $^{*}$
\end{tabular}

* after McCaffrey et al. (1987); ** after Valyashko (1962) 
fering $\mathrm{SO}_{4}^{2-}$ ions, and subsequently passed it through an $\mathrm{H}$-resin column to remove cations and convert the $\mathrm{Cl}^{-}$into $\mathrm{HCl}$. Finally, a pure $\mathrm{CsCl}$ solution was produced by passing the pure $\mathrm{HCl}$ solution through Cs-resin. This could then be analysed by mass spectrometry, using effectively the same methods as described by Vengosh et al. (1989), Xiao and Zhang (1992) and Xiao et al. (1995). Measurements were performed using a VG 354 thermal ionization mass spectrometer (Tan et al., 2006). The determinations of stable chloride isotope content were performed on two halite samples from the Yu-9 borehole (samples 14[2/57] and $33[34 / 61])$.

\section{RESULTS}

The tested halite crystals are large and clear. Large fluid inclusions ( $>100 \mu \mathrm{m})$ occur within transparent halite crystals of sample 33[34/61]. In the central parts, they preserve some parallel growth bands interpreted as primary fluid inclusions in chevrons (Fig. 4). On the periphery of chevron halite crystals there are large liquid inclusions. They are arranged without any regularity. Their shapes are close to cubic or irregular and the size varies from 0.2 to $1 \mathrm{~mm}$ (Fig. 5). Although these transparent parts of halite can form after sedimentary stage (during diagenesis), the co-existing primary fluid inclusions in the central portions of crystal imply that the halite was recrystallized at a very shallow depth. Homogenization temperature of fluid inclusions of sparry calcite filling pores of dolomites from Majiagou Formation range from $49-74^{\circ} \mathrm{C}$, and indicates recrystallization below $170 \mathrm{~m}$ (Zhang et al., 1997; Feng et al., 1998).

The major ion composition of inclusion brines has been determined in the primary fluid inclusions of sample Zjy-47-21 (Zhenjia-1 borehole) and in the secondary fluid inclusions of samples Yu-33[34/61] (Yu-9 borehole) and Zjy-24-57 (Zhenjia-1 borehole). In the remaining samples, there were not enough inclusions of suitable sizes to carry out UMCA studies.

The $\mathrm{Ca}^{2+}$ and $\mathrm{Mg}^{2+}$ concentrations were determined in brines from banded primary fluid inclusions of sample Zjy47-21. In the brine from six inclusions, the mean $\mathrm{Ca}^{2+}$ concentration was $66.1 \mathrm{~g} / \mathrm{l}$ (from 49.8 to $76.0 \mathrm{~g} / \mathrm{l}$ ). The mean $\mathrm{Mg}^{2+}$ con- centration was $41.3 \mathrm{~g} / \mathrm{l}$ (from 35.9 to $48.6 \mathrm{~g} / \mathrm{l}$ ), and the mean $\mathrm{K}^{+}$ concentration was $20.9 \mathrm{~g} / \mathrm{l}$ (from 17.3 to $23.1 \mathrm{~g} / \mathrm{l}$ ) (Table 2).

The $\mathrm{Ca}^{2+}$ and $\mathrm{Mg}^{2+}$ concentrations were also determined in brines from large secondary inclusions located in the outer edge of chevron halite crystals. The presence of K-Mg salt minerals in the inclusions provides the evidence of high concentration of parent brines (Table 3 ). The $\mathrm{Ca}^{2+}$ concentration was from 77.8 to $140.4 \mathrm{~g} / \mathrm{l}, \mathrm{Mg}^{2+}$ from 36.2 to $63.2 \mathrm{~g} / \mathrm{l}$, and the mean $\mathrm{K}^{+}$ concentration varied from 20.0 to $35.7 \mathrm{~g} / \mathrm{l}$ (Table 3 ).

The $\mathrm{Br}$ content in Ordovician halite is from $163 \mathrm{ppm}$ (sample $14[2 / 57]$ ) to $249 \mathrm{ppm}$ (sample 33[34/61]). The Br content of normal sea-originated halite ranges from 50 to $100 \mathrm{ppm}$, and increases to a maximum value of $277 \mathrm{ppm}$ at the onset of bittern precipitation (Valyashko, 1956). Thus, the Br contents in the Ordovician imply that the evaporation process can be near to bittern precipitation. It is also confirmed by potash minerals trapped within inclusions.

The $\delta^{37} \mathrm{Cl}$ values obtained for the Ordovician halite were -0.36 and $+0.24 \%$ o (Table 4 ).

\section{DISCUSSION}

In halite samples, both primary and secondary inclusions were found. Primary fluid inclusions are microdroplets of brine, trapped during crystal growth. These inclusions were usually arranged in bands located parallel to crystal growth faces (Fig. 4). Secondary fluid inclusions are usually large and can have a cubic shape and occur individually outside the primary structures (Fig. 5A). This kind of large fluid inclusions formed in early stages of diagenesis and their major ion compositions can be similar to those of primary fluid inclusions. There are also secondary large-size and irregular inclusions (Fig. 5B) and they are typical for recrystallized halite (Roedder et al., 1987; Kovalevich et al., 1998).

Previous studies (Roedder et al., 1987; Lazar and Holland, 1988; Bein et al., 1991; Kovalevich et al., 1998) showed that recrystallized halite, which originally precipitated from $\mathrm{SO}_{4}$-rich brines, could contain inclusions of two chemical assemblages: $\mathrm{SO}_{4}$-rich and $\mathrm{Ca}$-rich. Therefore, the occurrence of secondary $\mathrm{SO}_{4}$-rich inclusions also indicates that the basin brines and sea-

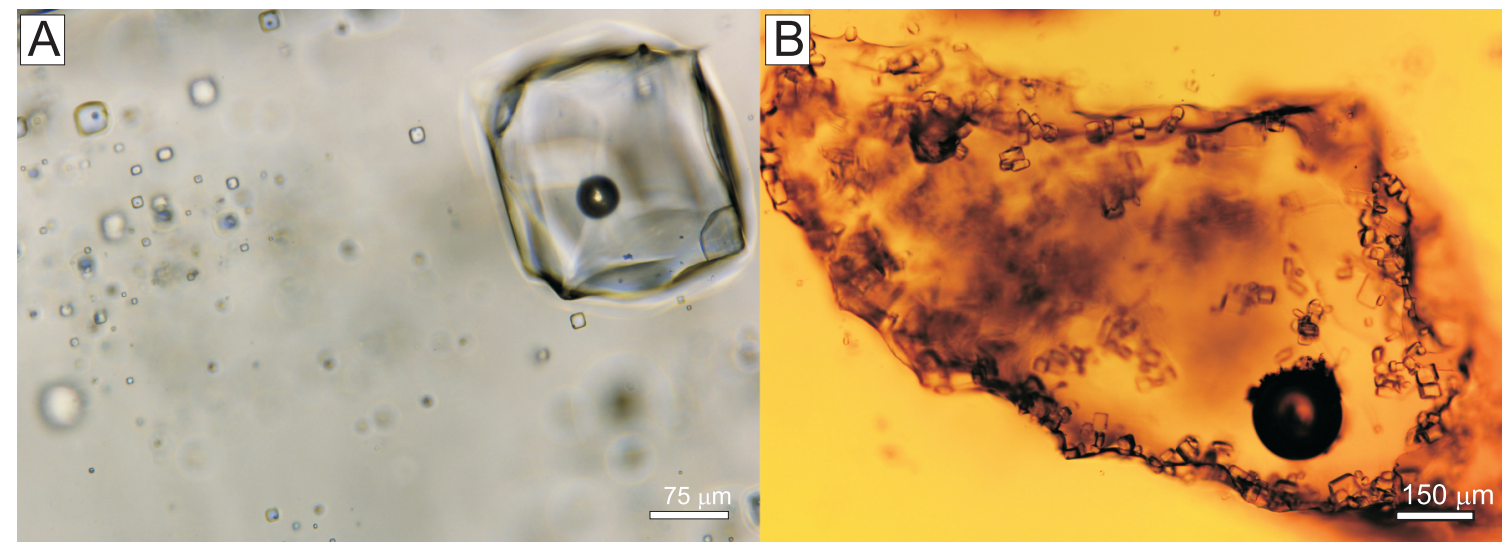

Fig. 5. Secondary fluid inclusions from the Yu-9 borehole

A - inclusion on the periphery of a sedimentary structure of halite; $\mathbf{B}$ - large multi-phase inclusion with numerous anisotropic crystals (anhydrite?) within clear, recrystallized halite 
Concentrations of major components in secondary fluid inclusions of halite from Ordovician halite

\begin{tabular}{|c|c|c|c|c|c|}
\hline \multirow{2}{*}{$\begin{array}{l}\text { Fluid inclusion, } \\
\text { No. }\end{array}$} & \multirow{2}{*}{$\begin{array}{c}\text { Concentration, } \\
\mathrm{g} / \mathrm{l} \text { (mean values } \\
\text { in brackets) }\end{array}$} & \multicolumn{4}{|c|}{ Remarks } \\
\hline & & $\mathrm{Mg}^{2+}$ & $\mathrm{Ca}^{2+}$ & $\mathrm{SO}_{4}^{2-}$ & \\
\hline \multicolumn{6}{|c|}{ Yu-9 borehole, sample 33[34/61] } \\
\hline 1 & $-^{*}$ & 63.2 & $136.9 ; 132.5 ; 151.7(140.4)$ & $<0.5$ & inclusion with sylvite daughter crystal \\
\hline 2 & - & - & $87.9 ; 75.8(81.9)$ & $<0.5$ & gas + liquid inclusions \\
\hline 3 & $\begin{array}{c}18.6 ; 21.4(20.0) \\
33.0^{\star *}\end{array}$ & - & - & $<0.5$ & sylvite occupies $\sim 1.3$ vol\% of the inclusion \\
\hline 4 & $\begin{array}{c}26.6 ; 22.8(24.7) \\
35.7^{\star *}\end{array}$ & - & - & $<0.5$ & sylvite occupies $\sim 1.1 \mathrm{vol} \%$ of the inclusion \\
\hline 5 & - & $\begin{array}{c}42.4 ; 32.3 \\
(37.4)\end{array}$ & $\begin{array}{c}124.5 ; 81.2 ; 111.5 ; 118.7 \\
98.9(106.9)\end{array}$ & $<0.5$ & inclusion with sylvite daughter crystal \\
\hline 6 & $\begin{array}{c}21.2 \\
31.2^{* *}\end{array}$ & $\begin{array}{c}43.0 ; 29.3 \\
(36.2)\end{array}$ & $131.2 ; 121.0(126.1)$ & $<0.5$ & sylvite occupies $\sim 1$ vol\% of the inclusion \\
\hline \multicolumn{6}{|c|}{ Zhenjia-1 borehole, sample Zjy-24-57 } \\
\hline 1 & $\begin{array}{c}21.2 ; 22.8(22.0) \\
34.0^{\star \star}\end{array}$ & 37.1 & $65.5 ; 73.2 ; 94.8(77.8)$ & $<0.5$ & sylvite occupies $\sim 1.2$ vol\% of the inclusion \\
\hline
\end{tabular}

* not determined; ** calculated value, based on volume of sylvite daughter crystal

Content of bromine, chloride and $\delta^{37} \mathrm{Cl}$ of the Ordovician halite samples from the Ordos Basin

\begin{tabular}{|c|c|c|c|c|}
\hline Sample & $\delta^{37} \mathrm{Cl}$ & Error SD $(n=3)$ & $\mathrm{Cl}$ [mass fraction, \%] & $\mathrm{Br}$ [ppm] \\
\hline Yu-9 borehole 14[2/57] & 0.24 & 0.15 & 60.34 & 163 \\
\hline Yu-9 borehole 33[34/61] & -0.36 & 0.09 & 60.31 & 249 \\
\hline
\end{tabular}

water were $\mathrm{SO}_{4}$-rich. In turn, entirely Ca-rich secondary inclusions suggest that the basin brines and seawater were Ca-rich. We have to stress that the study of secondary inclusions does not allow for estimation the ion ratios of contemporaneous brines and seawater (Kovalevych et al., 2006a).

The primary mineralogy of non-skeletal carbonate rocks and other evidences imply the Ordovician seawater should be of $\mathrm{Na}-\mathrm{K}-\mathrm{Mg}-\mathrm{Ca}-\mathrm{Cl}$ (Ca-rich) type and have a high $\mathrm{Ca}$ content (Sandberg, 1983; Kovalevich et al., 1998; Lowenstein et al., 2001). The speculation has no other evidence; however, the fluid inclusions in halite can provide the direct evidence.

The $\mathrm{Mg}^{+2}$ concentration in ancient seawater was in a direct relation with $\mathrm{SO}_{4}^{2-}$ concentration and in an inverse relation with $\mathrm{Ca}^{+2}$ concentration. This kind of relation caused significant changes of the $\mathrm{Mg}^{+2} / \mathrm{Ca}^{+2}$ ratio in seawater. The maximum $\mathrm{Mg}^{+2} / \mathrm{Ca}^{+2}$ ratios for the seawater of "calcite sea" times (rich in $\mathrm{Ca}$ and poor in $\mathrm{SO}_{4}$ ), such as Cambrian, Silurian, and Cretaceous, were found directly by the measurement of major compositions of fluid inclusions (Kovalevich et al., 1998; Lowenstein et al., 2001). The new data from primary fluid inclusions of Ordovician halite indicate that Middle Ordovician seawater was undoubtedly Ca-rich with the molar ratio $\mathrm{Mg}^{+2} / \mathrm{Ca}^{+2}=1.03$ (for medium values). These results are consistent with previous calculations considering the $\mathrm{Mg}^{+2} / \mathrm{Ca}^{+2}$ molar ratio in Ordovician seawater at $\sim 1.0$ (Lowenstein et al., 2001).
The $\delta^{37} \mathrm{Cl}$ values of Ordovician halite in this study were -0.36 and $+0.24 \%$. Because all published $\delta^{37} \mathrm{Cl}$ data for marine evaporites fall within a narrow range of $0.0 \pm 0.5 \%$ (Eastoe et al., 2007 with references), we conclude that $\delta^{37} \mathrm{Cl}$ values confirm a marine, origin of Ordovician salts of the Majiagou Formation.

\section{CONCLUSIONS}

Fluid inclusions in Ordovician marine halite provide direct evidence of Ca-rich Ordovician seawater (calcite sea) with $\mathrm{Na}-\mathrm{K}-\mathrm{Mg}-\mathrm{Ca}-\mathrm{Cl}$ composition. This study covers a huge gap on the evolution of seawater chemistry. A series of the bittern precipitates of late-stage potash salts in Ordovician marine evaporites is of $\mathrm{KCl}$ type (dominated by sylvite lacking primary $\mathrm{MgSO}_{4}$ salts). The brines from the secondary inclusions, located in the transparent parts of chevron halite and/or in the peripheries of crystals, showed a higher content of potassium and calcium than the brines from the primary inclusions. Based on our analysis of the chemical composition of the brines of the Cambrian, Ordovician and Silurian salt basins (Table 5), we could assume a higher potassium content in the Lower Paleozoic seawater. 
Average concentrations of major components in primary fluid inclusions of halite from the Cambrian, Îrdovician and Silurian deposits (halite precipitation stage)

\begin{tabular}{|c|c|c|c|c|c|c|c|c|c|c|c|c|}
\hline \multirow{2}{*}{ Location } & \multirow{2}{*}{$\begin{array}{c}\text { Period, } \\
\text { time }\end{array}$} & \multirow{2}{*}{$\begin{array}{l}\text { Age } \\
{[\mathrm{Ma}]}\end{array}$} & \multicolumn{2}{|c|}{ Ion content $[\mathrm{g} / \mathrm{l}]$} & \multicolumn{6}{|c|}{ Jänecke unit [mol \%] } & \multirow{2}{*}{$N / n^{*}$} & \multirow[b]{2}{*}{ References } \\
\hline & & & $\mathrm{K}^{+}$ & $\mathrm{Mg}^{2+}$ & $\mathrm{Ca}^{2+}$ & $\mathrm{SO}_{4}^{2-}$ & $\mathrm{K}$ & $\mathrm{Mg}$ & $\mathrm{Ca}$ & $\mathrm{SO}_{4}$ & & \\
\hline $\begin{array}{l}\text { Michigan Basin, } \\
\text { Salina Fm., USA }\end{array}$ & $\begin{array}{c}\mathrm{S}_{2} \\
\text { Ludlowian }\end{array}$ & $\sim 420$ & $\begin{array}{l}413^{* *} \\
(14.4) \\
\end{array}$ & $\begin{array}{c}1264^{* *} \\
(27.3) \\
\end{array}$ & $\begin{array}{l}831^{* *} \\
(29.7) \\
\end{array}$ & $<0.5$ & 9.0 & 54.9 & 36.1 & - & $41 / 46$ & $\begin{array}{c}\text { Brennan and } \\
\text { Lowenstein } \\
(2002) \\
\end{array}$ \\
\hline $\begin{array}{c}\text { Ordos Basin, } \\
\text { Majiagou Fm., China }\end{array}$ & $\mathrm{O}_{2}$ & $\sim 470$ & 20.9 & 41.3 & 66.1 & $<0.5$ & 7.4 & 47 & 45.6 & - & $1 / 3$ & Our data \\
\hline $\begin{array}{l}\text { East Siberian Basin, } \\
\text { Angara Fm., Russia } \\
\end{array}$ & $\begin{array}{c}\epsilon_{1} \\
\text { Toyonian } \\
\end{array}$ & $\sim 516$ & 20.2 & 35.5 & 50.1 & $<0.5$ & 8.7 & 49.2 & 42.1 & - & $5 / 13$ & $\begin{array}{r}\text { Petrichenko } \\
\text { et al. (2005) }\end{array}$ \\
\hline $\begin{array}{l}\text { East Siberian Basin, } \\
\text { Belsk Fm., Russia }\end{array}$ & $\begin{array}{c}\in_{1}, \\
\text { Botomanian }\end{array}$ & -519 & 20.7 & 46,8 & 59.1 & $<0.5$ & 7.2 & 52.6 & 40.2 & - & $1 / 5$ & $\begin{array}{l}\text { Petrichenko } \\
\text { et al. (2005) }\end{array}$ \\
\hline $\begin{array}{l}\text { East Siberian Basin, } \\
\text { Usolsk Fm., Russia }\end{array}$ & $\begin{array}{c}\in_{1}, \\
\text { Atdabanian } \\
\text { Tommotian }\end{array}$ & $\sim 519-530$ & 23.3 & 33.9 & 52.6 & $<0.5$ & 9.9 & 46.4 & 43.7 & - & $5 / 5$ & $\begin{array}{l}\text { Petrichenko } \\
\text { et al. (2005) }\end{array}$ \\
\hline \multicolumn{13}{|c|}{ Modern seawater concentrated to the beginning of precipitation of: } \\
\hline Halite & 3.9 & 12,6 & 0.22 & 17.6 & 6.7 & 68.9 & - & 24.4 & & \multicolumn{3}{|c|}{ McCaffrey et al. (1987) } \\
\hline Epsomite & 26.1 & 85,9 & - & 115.0 & & & - & & & \multicolumn{3}{|c|}{ McCaffrey et al. (1987) } \\
\hline Sylvite & 33.8 & 75,7 & - & 79.1 & & & - & & & \multicolumn{3}{|c|}{ Valyashko (1962) } \\
\hline
\end{tabular}

${ }^{*} \mathrm{~N} / \mathrm{n}$ - ratio of the number of results included into table $(N)$ to the overall number of studied samples (n)

${ }^{* *}$ Values in millimoles/kg $\mathrm{H}_{2} \mathrm{O}$; in brackets - calculated approximate value in $\mathrm{g} / \mathrm{l}$

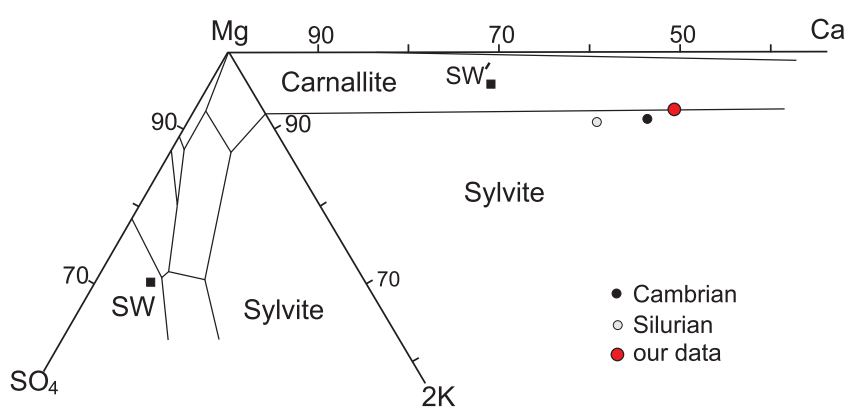

Fig. 6. Compositions of fluid inclusions in halite from Cambrian, Middle Ordovician and Silurian salts in the $\mathrm{Mg}-2 \mathrm{~K}-\mathrm{SO}_{4}$ and $\mathrm{Mg}-\mathrm{Ca}-2 \mathrm{~K}$ Jänecke diagrams at $25^{\circ}$ (diagrams after Eugster et al., 1980: fig. 9)

SW - modern seawater saturated with respect to halite (after

McCaffrey et al., 1987), SW' - ancient seawater ( $\in-\mathrm{C}, \mathrm{J}-\mathrm{K})$ saturated with respect to halite (after Kovalevich, 1990)

The $\delta^{37} \mathrm{Cl}$ values of chloride isotopes of Ordovician halite are close to $0.0 \%$ and can be explained by the precipitation from marine brines. These values are compatible with those measured in earlier studies of other Phanerozoic marine halite. Our results recorded moderately high bromine contents (163 pp and $249 \mathrm{ppm}$ ) for primary halite and support the conclusion on the marine genesis of these salts, close to the beginning of bittern crystallization.
Acknowledgements. This research was supported by National Natural Science Foundation of China (Nos: 41473039 and 4151101015), AGH grant No. 11.11.140.320 (to KB) and Bureau of International Co-operation, Chinese Academy of Sciences. We thank D.I. Cendón and S. Shekhunova for their critical comments. 


\section{REFERENCES}

Ayora, C., Cendón, D.I., Taberner, C., Pueyo, J.J., 2001. Brine-mineral reactions in evaporite basins: implications for the composition of ancient oceans. Geology, 29: 251-254.

Bao, H.P., Yang, C.Y., Huang, J.S., 2004. "Evaporation drying" and "reinfluxing and redissolving"-a new hypothesis concerning formation of the Ordovician evaporites in eastern Ordos Basin (in Chinese with English summary). Journal of Palaeogeography, 6: 279-288

Bein, A., Hovorka, S.D., Fisher, R.S., Roedder, E., 1991. Fluid inclusions in bedded Permian halite, Palo Duro Basin, Texas: evidence for modification of seawater in evaporite brine-pools and subsequent early diagenesis. Journal of Sedimentary Petrology, 61: 1-14.

Brennan, S.T., Lowenstein, T.K., 2002. The major-ion composition of Silurian seawater. Geochimica et Cosmochimica Acta, 66: 2683-2700.

Brennan, S.T., Lowenstein, T.K., Cendón, D.I., 2013. The major-ion composition of Cenozoic seawater: the past 36 million years from fluid inclusions in marine halite. American Journal of Science, 313: 713-775.

Cendón, D.I., Ayora, C., Pueyo, J.J., Taberner, C., 2003. The geochemical evolution of the Catalan potash subbasin, South Pyrenean Foreland basin (Spain). Chemical Geology, 200: 339-357.

Cendón, D.I., Ayora, C., Pueyo, J.J., Taberner, C., Blanc-Valleron, M.-M., 2008. The chemical and hydrological evolution of the Mulhouse potash basin (France): are "marine" ancient evaporites always representative of synchronous seawater chemistry? Chemical Geology, 252: 109-124.

Eastoe, C.J., Peryt, T.M., Petrychenko, O.Y., Geisler-Cussey, D., 2007. Stable chlorine isotopes in Phanerozoic evaporites. Applied Geochemistry, 22: 575-588.

Eugster, H.P., Harvie, C.E., Weare, J.H., 1980. Mineral equilibria in a six-component seawater system, Na-K-Mg-Ca-SO $-\mathrm{Cl}-\mathrm{H}_{2} \mathrm{O}$, at $25^{\circ} \mathrm{C}$. Geochimica et Cosmochimica Acta, 44: 1335-1347.

Feng, Z.Z., Zhang, Y.S., Jin, Z.K., 1998. Type, origin, and reservoir characteristics of dolostones of the Ordovician Majiagou Group, Ordos, North China platform. Sedimentary Geology, 118: 127-140.

Fox, J.S., Videtich, P.E., 1997. Revised estimate of $\delta^{34}$ S for marine sulfates from the Upper Ordovician: data from the Williston Basin, North Dakota, USA. Applied Geochemistry, 12: 97-103.

Galamay, A.R., Bukowski, K., Czapowski, G., 2003. Chemical composition of brine inclusions in halite from clayeysalt (zuber) facies from the Upper Tertiary (Miocene) evaporite basin (Poland). Journal of Geochemical Exploration, 78-79: 509-511.

García-Veigas, J., Ortí, F., Rosell, L., Ayora, C., Rouchy, J.-M., Lugli, S., 1995. The Messinian salt of the Mediterranean: geochemical study of the salt from the Central Sicily Basin and comparison with the Lorca Basin (Spain). Bulletin de la Société Géologique de France, 166: 699-710.

García-Veigas, J., Cendón, D.I., Pueyo, J.J., Peryt, T.M., 2011. Zechstein saline brines in Poland, evidence of overturned anoxic ocean during the Late Permian mass extinction event. Chemical Geology, 290: 189-201.

García-Veigas, J., Cendón, D.I., Rosell, L., Ortí, F., Torres Ruiz, J., Martín, J.M., Sanz, E., 2013. Salt deposition and brine evolution in the Granada Basin (Late Tortonian, SE Spain). Palaeogeography, Palaeoclimatology, Palaeoecology, 369: 452-465.

Hardie, L.A., 1996. Secular variation in seawater chemistry: an explanation for the coupled secular variation in the mineralogies of marine limestones and potash evaporites over the past $600 \mathrm{~m}$.y. Geology, 24: 279-283.

Horita, J., Zimmermann, H., Holland, H.D., 2002. Chemical evolution of seawater during the Phanerozoic: implications from the record of marine evaporates. Geochimica et Cosmochimica Acta, 66: 3733-3756

Khmelevska, O., Kovalevych, V., Peryt, T.M., 2000. Changes of seawater compositon in the Triassic-Jurassic time as recorded by fluid inclusions in halite. Journal of Geochemical Exploration, 69-70: 83-86.

Klein-BenDavid, O., Sass, E., Katz, A., 2004. The evolution of marine evaporitic brines in inland basins: the Jordan-Dead Sea Rift valley. Geochimica et Cosmochimica Acta, 68: 1763-1775.

Kovalevich, V.M., 1990. Halogenesis and chemical evolution ocean in the Phanerozoic (in Russian). Naukova Dumka, Kiev.

Kovalevich, V.M., Peryt, T.M., Petrichenko, O.I., 1998. Secular variation in seawater chemistry during the Phanerozoic as indicated by brine inclusions in halite. Journal of Geology, 106: 695-712.

Kovalevych, V., Vovnyuk, S., 2010. Fluid inclusions in halite from marine salt deposits: are they real micro-droplets of ancient seawater? Geological Quarterly, 54 (4): 401-410.

Kovalevych, V., Peryt, T.M., Beer, W., Geluk, M., Hałas, S., 2002. Geochemistry of Early Triassic seawater as indicated by study of the Rot halite in the Netherlands, Germany, and Poland. Chemical Geology, 182: 549-563.

Kovalevych, V.M., Carmona, V., Pueyo, J.J., Peryt, T.M., 2005. Ultramicrochemical analyses (UMCA) and Cryogenic Scanning Electron Microscopy (Cryo-SEM-EDS) of brines in halite-hosted fluid inclusions: a comparative study of analytical data. Geochemistry International, 43: 268-276.

Kovalevych, V.M., Marshall, T., Peryt, T.M., Petrychenko, O.Y., Zhukova, S.A., 2006a. Chemical composition of seawater in Neoproterozoic: results of fluid inclusion study of halite from Salt Range (Pakistan) and Amadeus Basin (Australia). Precambrian Research, 144: 39-51.

Kovalevych, V.M., Peryt, T.M., Zang, W.L., Vovnyuk, S.V., 2006b. Composition of brines in halite-hosted fluid inclusions in the Upper Ordovician, Canning Basin, Western Australia: new data on seawater chemistry. Terra Nova, 18: 95-103.

Kovalevych, V., Paul, J., Peryt, T.M., 2009. Fluid inclusions in halite from the Röt (lower triassic) salt deposit in central Germany: evidence for seawater chemistry and conditions of salt deposition and recrystallization. Carbonates and Evaporites, 24: 45-57.

Lowenstein, T.K., Timofeeff, M.N., Brennan, S.T., Hardie, L.A., Demicco, R.V., 2001. Oscillations in Phanerozoic seawater chemistry: evidence from fluid inclusions. Science, 294: 1086-1088.

Lazar, B., Holland, H.D., 1988. The analysis of fluid inclusions in halite. Geochimica et Cosmochimica Acta, 52: 485-490.

Li, R.X., Guzmics, T., Liu, X.J., Xie, G.C., 2011. Migration of immiscible hydrocarbons recorded in calcite-hostedfluid inclusions, Ordos Basin: a case study from Northern China. Russian Geology and Geophysics, 52: 1491-1503.

Lu, F., Tan, X., Ma, T., Li, L., Zhao, A., Su, C., Wu, J., Hong, H., 2017. The sedimentary facies characteristics and lithofacies palaeogeography during Middle-Late Cambrian, Sichuan Basin and adjacent area. Petroleum, 3: 212-231.

McCaffrey, M.A., Lazar, B., Holland, H.D., 1987. The evaporation path of seawater and the coprecipitation of $\mathrm{Br}$ and $\mathrm{K}$ with halite. Journal of Sedimentary Petrology, 57: 928-937.

Meng, F.W., Galamay, A.R., Yang, C.H., Li, Y.P., Zhuo, Q.G., 2014. The major composition of a middle-late Eocene salt lake in the Yunying depression of Jianghan Basin of Middle China based on analyses of fluid inclusions in halite. Journal of Asian Earth Sciences, 85: 97-105.

Petrichenko, O.I., 1973. Methods of study of inclusions in minerals of saline deposits (in Ukrainian: translated in Fluid Inclusions Research COFFI, 12: 214-274, 1979). Naukova Dumka, Kiev.

Petrychenko, O.Y. Peryt, T.M., Chechel, E.I., 2005. Early Cambrian seawater chemistry from fluid inclusions in halite from Siberian evaporites. Chemical Geology, 219: 149-161.

Porter, S.M., 2007. Seawater chemistry and early carbonate biomineralization. Science, 316: 1302-1302. 
Ren, Y., Zhong, D., Gao, C., Yang, Q., Xie, R., Jia, L., Jiang, Y., Zhong, N., 2017. Dolomite geochemistry of the Cambrian Longwangmiao Formation, eastern Sichuan Basin: implication for dolomitization and reservoir prediction. Petroleum Research, 2: 64-76.

Roedder, E., D’Angelo, W.M., Dorzapf, A.F., Aruscovage, P.J., 1987. Composition of fluid inclusions in Permian salt beds, Palo Duro Basin, Texas, USA. Chemical Geology, 61: 79-90.

Ronov, A.B., Khain, V.E., Balukhovsky, A.N., Seslavinsky, K.B., 1980. Quantitative analysis of Phanerozoic sedimentation. Sedimentary Geology, 25: 311-325.

Sandberg, P.A., 1983. An oscillating trend in Phanerozoic non-skeletal carbonate mineralogy. Nature, 305: 19-22.

Tan, H.B., Ma, H.Z., Wei, H.Z., Xu, J.X., Li, T.W., 2006. Chlorine, sulfur and oxygen isotopic constraints on ancient evaporite deposit in the Western Tarim Basin, China. Geochemical Journal, 40: $569-577$.

Wang, B.Q., Al-Aasm, I.S., 2002. Karst-controlled diagenesis and reservoir development; example from the Ordovician mainreservoir carbonate rocks on the eastern margin of the Ordos basin, China. AAPG Bulletin, 86: 1639-1658.

Valyashko, M.G., 1956. Geochemistry of bromine in the processes of salt deposition and the use of the bromine content as a genetic and prospecting criterion. Geochemistry (6): 570-589.

Valyashko, M.G., 1962. The principle of forming of salt deposits (in Russian). Moscow, MGU.
Vengosh, A., Chivas, A.R., McCullonch, M.T., 1989. Direct determination of boron and chlorine isotopes in geological materials by negative thermal-ionization mass spectrometry. Chemical Geology, 79: 333-343.

Yang, Y., Li, W., Ma, L., 2005. Tectonic and stratigraphic controls of hydrocarbon systems in the Ordos basin: a multicycle cratonic basin in central China. AAPG Bulletin, 89: 255-269.

Yao, J.L., Wei, X.L., Zhang, D.F., Wang, S.F., Huang, D.J., Ji, H.K., 2010. Sedimentary microfacies of anhydrite concretion dolomite rock: Take Majiagou Formation Ma5 ${ }_{1}{ }^{3}$ layer in the eastern Ordos Basin as an example (in Chinese with English summary). Petroleum Exploration and Development, 37: 690-695.

Zhang, Y.S., Zhang, C.I., Kang, Q.F., 1997. Inclusion study of massive dolostones of Ordovician Majiaggou Group in Ordos Basin (in Chinese with English abstract). Acta Petrologica Mineralogica, 16: 213-219.

Xiao, Y., Zhang, C., 1992. High precision isotopic measurement of chlorine by thermal ionization mass spectrometry of the $\mathrm{Cs}_{2} \mathrm{Cl}^{+}$ ion. International Journal of Mass Spectrometry and Ion Processes, 116: 183-192.

Xiao, Y., Zhou, Y., Liu, W., 1995. Precise measurement of chlorine isotopes based $\mathrm{Cs}_{2} \mathrm{Cl}^{+}$by thermal ionization mass spectrometry. Analytical Letters, 28: 1295-1300. 